Monetary policy and fiscal stimulus with the zero lower bound and financial frictions

R. Merola

Discussion Paper 2012-24

Institut de Recherches Économiques et Sociales de I'Université catholique de Louvain

IRES 


\title{
Monetary policy and fiscal stimulus with the zero lower bound and financial frictions
}

\author{
Rossana Merola* \\ OECD Economics Department \\ Universitè Catholique de Louvain la neuve
}

October 2012

\begin{abstract}
Recent developments in many industrialized countries have triggered a debate on whether monetary policy is effective when the nominal interest rate is close to zero. When the nominal interest rate hits its lower bound, the monetary authority is no longer in a position to pursue a policy of monetary easing by lowering nominal interest rates further. In this paper, I assess the implications of the zero lower bound in a DSGE model with financial frictions. The analysis shows that in a framework with financial frictions, when the interest rate is at the lower bound, the initial impact of a negative shock is amplified and the economy is more likely to plunge into a recession. I assess whether different macro policies, such as the management of expectations by the central bank or a counter-cyclical fiscal stimulus, may help recover
\end{abstract}

*Part of this work was done while the author was visiting the National Bank of Belgium, whose kind hospitality is gratefully acknowledged. I am grateful to Raf Wouters for his excellent supervision and Olivier Pierrard, Céline Poilly, Paul Reding and Henri Sneessens for valuable comments and suggestions. I am also indebted to Michel Juillard, Ragna Alstadheim and participants in the 6th Dynare Conference at Bank of Finland in June 2010. I thank Douglas Sutherland and economists working at the OECD Economics Department for useful discussion. I take full responsibility for any errors or omissions. The views expressed in this paper are my own and do not necessarily reflect the opinions of the OECD. Author contact: OECD, 2 rue André-Pascal, 75775 Paris CEDEX 16, Email: rossana.merola@oecd.org and rossana.merola@gmail.com. 
the economy from the recession. I find that the monetary authority might alleviate the recession by targeting the price-level. Fiscal stimulus represents an alternative solution especially when the zero lower bound constraint becomes binding, as fiscal multipliers may become larger than one. In analyzing discretionary fiscal policy, this paper also focuses on two crucial aspects: the duration of the fiscal stimulus and the presence of implementation lags.

JEL classification: E31, E44, E52, E58.

Keywords: Optimal monetary policy, financial accelerator, lower bound on nominal interest rates, price-level targeting, fiscal stimulus. 


\section{Contents}

1 Introduction 4

2 Model presentation $\quad \mathbf{8}$

2.1 Households . . . . . . . . . . . . . . . . . . . 9 9

2.2 Production sectors . . . . . . . . . . . . . . 10

2.2.1 Capital producers ................ . . . . 10

2.2.2 Entrepreneurs . . . . . . . . . . . . . . 11

2.2.3 Final goods producers . . . . . . . . . . . . . 14

2.2 .4 Retailers . . . . . . . . . . . . . 15

2.3 Monetary policy . . . . . . . . . . . . . . . 16

2.4 Calibration ...................... 17

3 The effects of the ZLB constraint and financial frictions 18

4 Is price-level targeting a solution? 21

5 The effectiveness of fiscal stimulus in times of crisis 23

6 Conclusions $\quad 28$ 


\section{Introduction}

By the second quarter of 2009, policy interest rates had fallen below one per cent in Canada, the United Kingdom, the euro area, Sweden, Switzerland, the United States and most of all Japan. These developments have triggered a debate on whether monetary policy is impotent at the zero bound and have hence revived interest in policies that might alleviate the costs associated with nominal interest rates close to the zero lower bound (hereafter, ZLB). On the one hand, price-level targeting (hereafter, PLT) has emerged as a potentially more successful strategy to anchor expectations than inflation targeting (e.g. Reifschneider and Williams (2000); Svensson (2000); Smets (2000); Gaspar and Smets (2000); Eggertsson and Woodford (2003); Amano and Ambler (2008); Coibon, Gorodinichenko and Wieland (2010)). The reason is that agents expecting policy to be loosened also expect future inflation to be higher, which in turn reduces real rates now and therefore reduces the amount by which the central bank needs to cut nominal rates to bring about the real rate stimulus it needs. ${ }^{1}$ On the other hand, with the prospect of a severe global recession following the 2007-2008 crisis, many governments have put forward fiscal stimulus plans in order to underpin a recovery ${ }^{2}$. The

\footnotetext{
${ }^{1}$ Nevertheless, the performance of a PLT rule needs to confront several issues. First, central banks need to establish credibility, otherwise the attractiveness of the price-level target vis-à-vis to an inflation target might be reduced. However, Cateau and Dorich (2011) point out that with an occasionally binding ZLB even an imperfectly credible PLT rule will dominate an inflation targeting rule. Second, the benefits of a PLT rule depend on the assumption that expectations are forward-looking. The beneficial impact of a PLT rule on inflation expectations was lacking in the first strand of theoretical analysis based on backward-looking models, as in Lebow, Roberts, and Stockton (1992), Haldane and Salmon (1995) and Fillion and Tetlow (1994).

${ }^{2}$ To list some examples: the American Recovery and Reinvestment Act in the United States; the "Konjunkturpakete I und II" in Germany; the "Plan de reliance" in France;
} 
supportive fiscal policy stance during the recession has been motivated by the belief that with policy interest rates near zero, the effectiveness of monetary policy is uncertain, and therefore a counter-cyclical fiscal stimulus could be more effective in pulling the economy out from recession (e.g. Christiano, Eichenbaum and Rebelo (2011); Erceg and Lindé (2009); Woodford (2011)).

The ZLB continues to pose challenges also in the aftermath of the global recession. Several major economies are likely to face imminent deleveraging that will limits the borrowing capacity of debtors with a high marginal propensity to consume. The presence of the ZLB on nominal interest rates could prevent central banks from reducing interest rate sufficiently in order to induce creditors to spend more, and thus offset the decline in spending by debtors. Motivated by these developments, this paper has two aims. First, it assesses whether a lower bound on nominal interest rates might deepen the recession, in the presence of frictions in financial markets. Second, it evaluates the extent to which macroeconomic policies (namely, a price-level target and fiscal stimulus) might alleviate problems posed by the ZLB.

The ZLB constraint combined with the financial accelerator mechanism (hereafter, FA) remains an open issue to be explored. The literature has so far focused either on the macroeconomic policies that might alleviate problems posed by the ZLB (e.g. Reifschneider and Williams (2000); Eggertsson and Woodford (2003); Gaspar and Smets (2000); Amano and Ambler (2008), Christiano, Eichenbaum and Rebelo (2011); Erceg and Lindé (2009); Woodford (2011)) or on the role of fiscal policy in a framework with financial frictions (e.g. Fernández-Villaverde). However, the literature remains scarce the "Pacchetto fiscale" in Italy; the "El Plan E" in Spain. 
on the implications of the ZLB in a framework with financial frictions. To my knowledge, the only work that sheds light on this aspect is Carillo and Poilly (2010). In this paper, I contribute to the existing literature by introducing financial frictions in a DSGE model with a binding ZLB constraint. This provides insights to the analysis of the implications of the ZLB constraint in a framework with financial frictions.

The structure of the model is a closed economy DSGE model which contains standard features, such as investment adjustment costs and sticky prices. In addition, I add financial frictions that are formalized as in Bernanke Gertler and Gilchrist (1995) and Bernanke and Gertler (1989, 1998). The source of the financial accelerator is the asymmetric information that will make it costly for lenders to evaluate the quality of enterprises' investments. For this reason, lenders require a premium for external funds over the riskfree interest rate. Bernanke Gertler and Gilchrist (1995) show that under the optimal contract, the external finance risk premium depends on the enterprises' balance sheet position. Therefore, the financial accelerator mechanism introduces a positive relationship between the external finance premium and entrepreneurs' net worth. The underlying mechanism works in the following way. During a financial downturn, adverse shocks lower current cash flows and hence reduce the ability of firms to self-finance investment projects. This decline in net worth raises the external finance premium and the cost of new investments. Falling investment reduces economic activity and cash flow in subsequent periods, amplifying and propagating the effect of the initial shock. A binding ZLB constraint on nominal interest rates might hinder the recovery, as central banks are no longer able to counter the recessionary spiral 
triggered by the financial accelerator mechanism.

Several interesting results are derived. First, in a framework with financial frictions, the ZLB amplifies the effects of a negative shock by hindering the ability of the central bank to offset the negative effects of an adverse shock. Second, the price level is a better target than inflation in order to prevent the ZLB being reached, as it lifts inflation expectations in the face of deflationary shocks. Third, in such a framework with financial frictions and lower interest rate, a counter-cyclical fiscal stimulus could be more effective in helping the economy recover from recession. The ZLB amplifies the stimulative effect of the fiscal intervention. This latter result is in line with Carillo and Poilly (2010), but holds in a more general context. While in Carillo and Poilly (2010), this results hinges on the assumption of nominal liabilities and works through the debt-deflation effect, here the mechanism is more simple: the higher inflation generated by the fiscal stimulus reduces the real interest rate and this channel supports investment and amplifies the impact of the fiscal stimulus on GDP. Therefore, the assumption of nominal liability is not a necessary condition to conclude in favour of fiscal stimulus in the proximity of the ZLB. Moreover, compared to Carillo and Poilly (2010), this paper sheds light on additional aspects, including the timing and the duration of the fiscal stimulus as well as the benefits of a PLT rule. Results demonstrate that to be effective, fiscal stimulus should be implemented promptly and need to be removed when the ZLB ceases to bind.

The paper is structured as follows. In section 2, I develop the model. In section 3, I investigate whether the lower bound enhances the negative effects of adverse shocks and whether the introduction of the financial accelerator 
makes the lower bound constraint more likely. In section 4 and section 5, I discuss to what extent monetary and fiscal policy might alleviate the effects of the ZLB, assessing the benefits of a price-level targeting rule and fiscal stimulus. Section 6 concludes.

\section{Model presentation}

The model used is a closed economy DSGE model similar to Christensen and Dib (2006). The model contains standard features, such as adjustment cost on investment and sticky prices. In addition, I add financial frictions as in Bernanke Gertler and Gilchrist (1995) and Bernanke and Gertler (1989, 1998).

There are five sectors in the economy: households, entrepreneurs, capital producers, retailers and final goods producers. Households finance entrepreneurs' purchase of capital by lending deposits. The presence of asymmetric information between entrepreneurs and lenders creates financial frictions which make entrepreneurial demand for capital depend on their financial position. Capital producers build unfinished capital and sell it to entrepreneurs. Competitive final good firms combine final capital goods produced by entrepreneurs and labour supplied by households. They combine these two factors to produce a homogeneous final good. Retailers are the source of nominal frictions. They differentiate the homogeneous final good and sell it in monopolistically competitive retail markets. They set nominal prices in a staggered fashion à la Calvo. Finally, I assume that exogenous shocks are sufficiently large to force the nominal interest rate to hit its ZLB on impact. 
When the ZLB constraint becomes binding, the nominal interest rate is kept constant at the zero value, while when the ZLB is not binding the monetary authority sets the nominal interest rate, according to a standard Taylor rule.

\section{$2.1 \quad$ Households}

Preferences of households at time $t$ are described by:

$$
\max U_{t}=E_{0} \sum_{t=0}^{\infty} \beta^{t} u\left(C_{t}, H_{t}\right)
$$

where $\beta$ is the discount factor, $C_{t}$ is a composite consumption index and $H_{t}$ is labour supply. Let the functional form of $u$ be given by:

$$
u\left(C_{t}, H_{t}\right)=\frac{1}{1-\sigma}\left(C_{t}\right)^{1-\sigma}-\frac{H_{t}^{1+\psi}}{1+\psi}
$$

A consumer's revenue flow comes from her supply of hours of work to firms for wages $W_{t}$, profits $\Pi_{t}$ from firms and the return on assets $B_{t}$, net of lump-sum taxes.

$$
P_{t} C_{t}=W_{t} H_{t}+\Pi_{t}-\operatorname{Tax}_{t}+B_{t-1}-\frac{B_{t}}{\left(R_{t-1} Z_{t}\right)}
$$

The first order conditions (hereafter, f.o.c.) from the maximization problem are:

$$
\begin{aligned}
& \frac{\lambda_{t}}{R_{t} Z_{t}}=\beta E_{t}\left(\lambda_{t+1}\right) \\
& \lambda_{t}=C_{t}^{-\sigma} \\
& w_{t}=\left(-\frac{U_{H t}}{U_{C t}}\right)=H^{\psi}\left(C_{t}\right)^{\sigma}
\end{aligned}
$$


where $\lambda_{t}$ is the Lagrangian multiplier associated with the budget constraint and $w_{t}$ is the real wage. The disturbance term $Z_{t}$ represent a risk premium shock. ${ }^{3}$ It drives a wedge between the interest rate controlled by the central bank and the return on assets held by households. A positive risk premium shock increases the return on assets held by households and hence increases savings and reduces current consumption. At the same time, this shock also increases the cost of capital and reduces investment. The risk premium shock helps to explain the comovements of consumption and investment. ${ }^{4} Z_{t}$ follows the first-order autoregressive process: $Z_{t}=\bar{Z}^{1-\rho_{Z}} Z_{t-1}^{\rho_{Z}} \exp \left(\varepsilon_{Z_{t}}\right)$ where $\rho_{Z} \in$ $(0,1)$ is an autoregressive coefficient and $\varepsilon_{Z_{t}}$ is normally distributed with mean zero and standard deviation $\sigma_{Z}$.

Finally, for the Fisher condition, the real interest rate $R_{t}$ is defined as follows: $R_{t}=R_{t}^{n} \frac{P_{t}}{P_{t+1}}$ where $R_{t}^{n}$ is the gross nominal interest rate.

\subsection{Production sectors}

\subsubsection{Capital producers}

Production of unfinished capital goods is carried out by competitive firms. Newly produced capital goods replace depreciated capital and add to the capital stock. I assume that capital producers are subject to quadratic capital adjustment costs, so that the marginal return to investment in terms of capital goods is declining in the amount of investment undertaken, relative to the current capital stock. Capital producers make their production plans

\footnotetext{
${ }^{3}$ In modelling the risk premium shock, I follow Smets and Wouters (2007).

${ }^{4}$ This effect makes this shock different from a discount factor shock as in Christiano, Eichenbaum and Rebelo (2009).
} 
one period in advance. They maximize

$$
\max E_{t-1}\left\{\left[Q_{t} I_{t}-I_{t}-\frac{\chi}{2}\left(\frac{I_{t}}{K_{t-1}}-\delta\right)^{2}\right] K_{t}\right\}
$$

The f.o.c. gives the standard Tobin's Q equation:

$$
Q_{t}=1+\chi\left(\frac{I_{t}}{K_{t-1}}-\delta\right)
$$

Furthermore, the capital stock evolves according to:

$$
K_{t+1}=I_{t}+(1-\delta) K_{t}
$$

In addition, total output is also determined by exogenous government spending $G_{t}$. I assume that exogenous spending follows a first-order autoregressive process: $G_{t}=\rho_{G} G_{t-1}+\varepsilon_{G_{t}}$ where $\rho_{G} \in(0,1)$ is an autoregressive coefficient and $\varepsilon_{G_{t}}$ is normally distributed with mean zero and standard deviation $\sigma_{G}$.

Final output is the sum of consumption, investment goods and government spending

$$
Y_{t}=C_{t}+I_{t}+G_{t}
$$

\subsubsection{Entrepreneurs}

The entrepreneurs' behaviour is modelled along the line of Bernanke, Gertler and Gilchrist (hereafter, BGG). ${ }^{5}$ The source of financial frictions is the existence of an agency problem that makes external finance more expensive than

\footnotetext{
${ }^{5}$ In the standard financial accelerator framework, BGG assume that there exists an idiosyncratic shock that affects the ex-post return on capital for entrepreneurs and hence determines the riskiness of entrepreneurs. Once the cut-off value of the idiosyncratic shock is obtained, one can compute the implied risk premium and the implied leverage ratio. In this paper, following Christensen and Dib (2006), I adopt an ad hoc functional form for the external finance risk premium that is increasing in the leverage ratio as in BGG (1999).This approach avoids a number of computational difficulties and refrains from
} 
internal funds. The entrepreneurs observe costlessly. their output which is subject to a random outcome. Lenders incur an auditing cost to observe an entrepreneur's output. After observing her project outcome, an entrepreneur decides whether to repay her debt or to default. If she defaults, the financial intermediary audits the loan and recovers the project outcome less monitoring costs. Accordingly, the marginal external financing cost is equal to a gross premium for external funds plus the gross real opportunity costs equivalent to the riskless interest rate. BGG show that the optimal contract implies that the external finance premium depends on the entrepreneurs' balance sheet position. In particular, the external finance premium increases with the leverage ratio. At the end of each period, entrepreneurs purchase capital that will be used in the next period. This capital purchase $\left(K_{t} Q_{t-1}\right)$ is partly financed through internal funds (entrepreneurs' net worth, $N_{t}$ ) and partly through external borrowing. The leverage ratio is defined as $\frac{K_{t} Q_{t-1}}{N_{t}}$ and the external finance premium can thus be characterized by a functional form of the type $s_{t}=s\left(\frac{K_{t} Q_{t-1}}{N_{t}} X_{t}\right)$ where $s^{\prime}(\bullet)>0$ and $s(1)=1$. The shock $X_{t}$ represents a financial shock to the external risk premium. It follows the first-order autoregressive process: $X_{t}=\bar{X}^{1-\rho_{X}} X_{t-1}^{\rho_{X}} \exp \left(\varepsilon_{X_{t}}\right)$ where $\rho_{X} \in(0,1)$ is an autoregressive coefficient and $\varepsilon_{X_{t}}$ is normally distributed with mean zero and standard deviation $\sigma_{X}$. The entrepreneurs' demand for capital depends on the marginal productivity of capital and on the capital making assumptions on the distribution of idiosyncratic shocks (see De Graeve (2007)). Moreover, in the standard BGG framework, the standard aggregate resource constraint is augmented with a term capturing the cost of bankruptcy. However, under a reasonable parametrization of the model, these costs are small and are therefore typically neglected (e.g. De Graeve (2007); Christensen and Dib (2006); Gilchrist, Ortiz and Zakrajšek (2009)). 
gain:

$$
E_{t}\left(F_{t+1}\right) Z_{t}=E_{t}\left\{\frac{r_{t+1}^{K}+(1-\delta) Q_{t+1}}{Q_{t}}\right\}
$$

where $F_{t+1}$ is the external funds rate and $r_{t+1}^{K}$ is the marginal productivity of capital, at $t+1$. The risk premium disturbance affects the cost of capital and not only the consumer Euler equation. This assumption allows commovements in consumption and investment to be modelled.

Thus, the demand for capital should satisfy the following optimality condition that states that the expected real return on capital is equal to the external financing cost:

$$
F_{t+1}=R_{t} s_{t}
$$

To determine the external finance premium, I adopt the following functional form:

$$
s_{t}=\left(\frac{K_{t+1} Q_{t}}{N_{t+1}} X_{t}\right)^{\omega}
$$

where $\omega>0$. Therefore, at time $t$, the gross external finance premium $\left(\frac{K_{t+1} Q_{t}}{N_{t+1}} X_{t}\right)^{\omega}$ depends on borrowers' leverage ratio $\left(\frac{K_{t+1} Q_{t}}{N_{t+1}}\right)$, the elasticity of the external finance premium with respect to the leverage ratio $(\omega)$ and the disturbance term $X_{t}{ }^{6}$

To ensure that entrepreneurs' net worth (the firm's equity) will never be sufficient to fully finance the new capital acquisition, following BGG, I assume that entrepreneurs have a finite life span. The probability that an

\footnotetext{
${ }^{6}$ In a model without financial frictions, the leverage ratio is equal to 1 and the elasticity $\omega=0$.
} 
entrepreneur will survive until the next period is $\nu$, so the expected lifetime horizon is $\frac{1}{1-\nu}$. The entrepreneur's aggregate net worth is the equity held by entrepreneurs surviving from the previous period, and it is defined as follows:

$$
N_{t+1}=\nu\left[F_{t} Q_{t-1} K_{t}-R_{t}\left(\frac{K_{t} Q_{t-1}}{N_{t}} X_{t}\right)^{\omega}\left(K_{t} Q_{t-1}-N_{t}\right)\right]+(1-\nu) D_{t}
$$

The term in brackets is the value of surviving entrepreneurial firms' capital, net of borrowing costs, carried over the previous period and $D_{t}$ is the transfer that $1-\nu$ newly entering entrepreneurs receive from entrepreneurs that die. The term $D_{t}$ ensures that new entrepreneurs can operate ${ }^{7}$.

\subsubsection{Final goods producers}

Production is carried out by firms that follow a constant-returns-to-scale technology. To produce output $Y_{t}$, firms combine final capital goods and labour. The technology is defined as follows:

$$
Y_{t}=A K_{t}^{\alpha} H_{t}^{1-\alpha}
$$

where $A$ is the productivity parameter. Firms minimize production costs, so the first order conditions are:

$$
\begin{aligned}
& w_{t}=m c_{t}(1-\alpha) \frac{Y_{t}}{H_{t}} \\
& r_{t}^{K}=m c_{t} \alpha \frac{Y_{t}}{K_{t-1}}
\end{aligned}
$$

where $m c_{t}$ denotes the marginal production cost for a firms.

\footnotetext{
${ }^{7}$ Following Gertler, Gilchrist and Natalucci (2007) and Christensen and Dib (2008), I assume that $D_{t}$ is of negligible size.
} 


\subsubsection{Retailers}

Retailers purchase the wholesale goods at a price equal to nominal marginal costs and differentiate them at no cost. They then sell these differentiated retail goods on a monopolistically competitive market.

Following Calvo, I am assuming that firms cannot change their selling prices unless they receive a random signal. The constant probability to receive such a signal is $(1-\varphi)$. Each firm $j$ sets the price $p_{t}^{*}(j)$ that maximizes the expected profit for $l$ periods, where $l=\frac{1}{1-\varphi}$ is the average length of time that a price remains unchanged. The maximization problem is ${ }^{8}$

$$
\begin{aligned}
& \operatorname{Max} E_{0} \sum_{t=0}^{\infty}\left[(\beta \varphi)^{l} \lambda_{t+l}\left(p_{t}^{*}(j)-m c_{t+l}\right) \frac{Y_{t+l}(j)}{P_{t+l}}\right] \\
& \text { s.t. } Y_{t+l}(j)=\left(\frac{p_{t}^{*}(j)}{P_{t+l}}\right)^{-\vartheta} Y_{t+l}
\end{aligned}
$$

The first order condition is:

$$
p_{t}^{*}(j)=\frac{\vartheta}{\vartheta-1} \frac{\left.E_{0} \sum_{t=0}^{\infty}\left[(\beta \varphi)^{l} \lambda_{t+l} m c_{t+l}\right) \frac{Y_{t+l}(j)}{P_{t+l}}\right]}{E_{0} \sum_{t=0}^{\infty}\left[(\beta \varphi)^{l} \lambda_{t+l} \frac{Y_{t+l}(j)}{P_{t+l}}\right]}
$$

The aggregate price is $P_{t}^{1-\vartheta}=(1-\varphi)\left(P_{t}^{*}\right)^{1-\vartheta}+\varphi P_{t-1}^{1-\vartheta}$. These equations lead to the following New Keynesian Phillips curve:

\footnotetext{
8 The demand function is derived from the definition of aggregate demand $Y_{t+l}=$ $\left(\int_{0}^{1} Y_{j t+l}^{\vartheta-1 / \vartheta} d j\right)^{\vartheta / \vartheta-1}$ and the corresponding price index in the monopolistic competition framework of Dixit and Stiglitz is $P_{t+l}=\left(\int_{0}^{1} p_{j t+l}^{1-\vartheta} d j\right)^{1 / 1-\vartheta}$ where $\vartheta$ is the elasticity of substitution between varieties of goods.
} 


$$
\pi_{t}=\frac{(1-\beta \varphi)(1-\varphi)}{\varphi} m \hat{c}_{t}+\beta E_{t} \pi_{t+1}
$$

where $\pi_{t}=\frac{P_{t}}{P_{t-1}}-1$ is the inflation rate and $m \hat{c}_{t}$ is the log deviation of real marginal cost from its steady-state level.

\subsection{Monetary policy}

I introduce the zero lower bound on the nominal interest rate, defining the Taylor rule in the following way:

$$
1+r_{t}^{n}=R_{t}^{n}=\max \left\{(1+0),\left[\left(\frac{1+\pi_{t}}{1+\bar{\pi}}\right)^{\gamma_{\pi}}\left(\bar{R}^{n}\right)\right]^{1-\rho_{R N}}\left(R_{t-1}^{n}\right)^{\rho_{R N}}\right\}
$$

The parameter $\gamma_{\pi}$ governs the degree to which the inflation rate is targeted around the desired target $\bar{\pi}$. Moreover, I am assuming that the monetary authority does not react immediately and adjust interest rate with a degree of inertia measured by $\rho_{R N} . \bar{R}^{n}$ denotes the steady-state of the gross nominal interest rate. According to equation $(22)^{9}$, if the ZLB is not binding the monetary authority follows a Taylor rule; if the ZLB is binding the monetary policy simply sets the nominal interest rate to zero ${ }^{10}$. The methodology adopted in

\footnotetext{
9 One caveat is that in this set-up, agents are not able to rationally anticipate the possibility of hitting the ZLB. Therefore they will not immediately reduce their output and inflation expectations correspondingly. Therefore, the policy response is less aggressive than in a model in which agents were able to anticipate the possibility of hitting the ZLB. For a further discussion of the role of expectations in models with a zero lower bound on interest rates, see Adam ad Billi (2006).

10 The condition $R_{t}^{n}>1$, in terms of deviation from the steady-state, becomes $R_{t}^{n}-\bar{R}=$ $\hat{R}_{t}^{n} \geq 1-\bar{R}$, where $\bar{R}$ is the steady-state value of the gross nominal interest rate, defined as $\overline{\bar{R}}=\left[(1+\pi) \beta^{-1}\right]$. Therefore $\hat{R}_{t}^{n}>1-\left[(1+\pi) \beta^{-1}\right]$. As the net nominal interest rate at the steady-state is defined as $\bar{r}=\left[(1+\pi) \beta^{-1}\right]-1$, in terms of percentage deviation from the steady-state equation (22) implies that when the ZLB is binding $\hat{R}_{t}^{n} \geq-\bar{r}$.
} 
the paper closely follows Cogan, Cwick, Taylor and Wieland (2010). Fiscal stimulus simulation with anticipated government spending plans and temporary constraints on the nominal interest rates require non-linear solution techniques. Dynare handles these non-linear solution techniques in a deterministic set-up.

\subsection{Calibration}

The model parameters are set to fit quarterly frequency. Table 1 summarizes the calibrated values. Following the literature, I set the steady-state rate of depreciation of capital $(\delta)$ equal to 0.025 which corresponds to an annual rate of depreciation equal to $10 \%$; the discount factor $\beta$ is equal to 0.99 , which corresponds to an annual real rate in steady-state of $4 \%$. Also other parameters fall in standard ranges. The relative risk aversion coefficient $(\sigma)$ is set equal to 1.2. The steady-state share of capital in the final goods production function $(\alpha)$ is equal to 0.35, as in Bernanke, Gertler and Gilchrist (1998). The elasticity of labour supply $(\psi)$ is set equal to 1 as in Christiano, Motto and Rostagno (2010). Following Christensen and Dib (2006) and Gertler, Gilchrist and Natalucci (2007), the steady-state value of the elasticity of substitution between varieties of goods is equal to 6 , which implies a mark-up of $20 \%$. The Calvo price parameter is set equal to 0.75 as in Bernanke, Gertler and Gilchrist (1998) and Christiano, Motto and Rostagno (2010). This means that firms re-optimize their prices every three quarters. The coefficient on inflation $\gamma_{\pi}$ is set equal to 1.5 , while the interest rate smoothing parameter $\rho_{R N}$ is equal to 0.8 . There is no consensus on the parameter $\chi$ describing investment adjustment costs. The estimates range from 
0.13 to 20 depending on the data set (micro vs. macro) and the estimation methodology (reduced form vs. structural or simulation-based methods). Gilchrist, Sim and Zakrajšek (2010) discusses how earlier literature finds a substantial degree of adjustment frictions at the micro level, while the more recent literature finds the strength of the friction much weaker. Considering this recent trend and following Gilchrist, Sim and Zakrajšek (2010), I set this parameter to 1.42. Finally, following Bernanke, Gertler and Gilchrist (1998) and Christiano, Motto and Rostagno (2010), the steady-state value of the leverage ratio is set equal to 2 and the probability $\nu$ that entrepreneurs will survive for the next period is set equal to 0.9728 , therefore on average entrepreneurs stay in business for 36 years. The steady-state of the external risk premium is roughly 350 basis points on annual basis, close to the value in Gertler, Gilchrist and Natalucci (2007). This value is higher than that one set by Bernanke, Gertler and Gilchrist (1998), as it takes into account that in most of the empirical literature, the risk premium is estimated to be roughly 320 basis points on annual basis (De Graewe (2008) and Queijo (2009)).

\section{The effects of the ZLB constraint and fi- nancial frictions}

In this section, I start assessing the implications of the ZLB constraint on the nominal interest rate in a model that entails financial frictions. Then I show that the presence of financial frictions makes the ZLB more likely to be hit.

For this purpose, I introduce two kinds of shocks: a negative demand 
shock (e.g. a risk premium shock) and an adverse financial shock (e.g. an increase in the external finance risk premium). Both shocks are modelled as an $A R(1)$ process with a fairly high degree of persistence (the autoregressive coefficient is set equal to 0.9 ). The risk premium shock by increasing (reducing) the interest rate encourages (discourages) saving and hence affects the lending side. The financial shock, by increasing the external finance risk premium, makes external borrowing more expensive. In other words, it represents a tightening of credit conditions and hence affects the borrowing side. These two types of shocks are suitable for analyzing the dynamics when the ZLB is binding, as they put downward pressure on both output and inflation, which can cause a binding ZLB. Therefore, this potentially creates a more severe downturn. I contrast the effects under normal situations (i.e. when the central bank has the ability to lower interest rates in response to the demand shock) with a situation when the nominal short-term interest rate is subject to the lower bound. Then, I analyze whether the economy is likely to be pushed into a more severe recession when the ZLB binds. Finally, I compare the model specification with financial frictions with that one without financial frictions, to assess the effect of financial frictions.

In Figure 1, I compare the responses to a risk premium shock under two alternative specifications of the model: the model without the ZLB constraint and a model which features a binding lower bound on the nominal interest rate. In this latter specification, the real interest rate is limited in its possibility to stimulate the economy, after the initial drop in consumption and output. A risk premium shock reduces both private consumption and investment. On the one hand, this shock stimulates private savings by increasing 
the required return on assets held by households. On the other hand, the price of capital drops, as it depends positively on its expected value and the expected rental capital rate and negatively on the ex-ante real risk-free interest rate and the risk premium disturbance. The collapse of the capital price translates into lower investment and capital. The drop of both consumption and investment results in lower output and lower inflation. The presence of the ZLB makes the drop in investment more severe, as the risk premium shock leads to a deterioration of the leverage ratio, an increase of the external finance risk premium and a reduction of entrepreneurial net worth. This mechanism is amplified when the ZLB constraint is binding and hence the increase in the external finance risk premium is stronger. As a consequence, the cost of new investment raises and the recession is amplified.

Figure 2 displays the response of the main macro variables to a financial shock that pushes up the external finance risk premium, worsening entrepreneurs' balance sheets. As enterprises are limited in their ability to self-finance, the level of investment falls and the economy is pushed onto a recessionary-deflationary path. The recession is amplified if the lower bound on the nominal interest rate is binding, as the monetary authority is no longer able to offset the negative effects of an adverse shock by using the nominal interest rate as an instrument.

Turning to the effect of financial frictions, the analysis of the responses to the risk premium shock allows an evaluation of whether the nominal interest rate is more likely to hit its ZLB in the presence of financial frictions. Figure 3 shows that the risk premium shock reduces both private consumption and investments. On one side, this type of shock stimulates private savings by 
increasing the required return on assets held by households. If the financial accelerator mechanism is operative, the initial shock is amplified. The underlying reasoning is the following: the price of capital depends negatively on the external financing cost, which is the risk-free real interest rate augmented by the financial risk premium. Therefore, in the presence of financial frictions, the collapse in the price of capital is amplified. The larger collapse in the price of capital under financial frictions is translated into a higher leverage ratio which further raises the average external finance premium and the cost of new investments. Declining investments lower economic activity and cash flow in subsequent periods, amplifying and propagating the effect of the initial shock. The collapse in output results in lower inflation and both effects are translated into a lower nominal interest rate. As the recession is magnified by the financial accelerator mechanism, in the model with financial frictions the decrease in the nominal interest rate is more accentuated and prolonged. Therefore, the presence of financial frictions brings the interest rate closer to the $\mathrm{ZLB}$.

\section{Is price-level targeting a solution?}

In this section, I explore the issue of whether the price level is a better target for monetary policy in order to limit the probability of hitting the ZLB. The motivation is that - when expectations are forward-looking - a PLT rule introduces a desirable inertia that affects the private sector's expectations; hence it results in less volatile interest rates.

The mechanism operates as follows. Assume that a deflationary distur- 
bance leads to a fall in the price level relative to the target (e.g. a negative demand shock). Economic agents observing the shock understand that the central bank will correct the deviation from the target aiming at an aboveaverage inflation rate. As a result, inflation expectations increase, which helps to mitigate the initial impact of the deflationary shock. Under a credible price level target, inflation expectations operate as automatic stabilizers.

The main difference between inflation-targeting (hereafter, IT) and PLT is that, under IT, unexpected disturbances to the price-level are ignored, while under PLT they are reversed. This implies that, under PLT, the price level has a predetermined targeted path and uncertainty about the future price level is bounded.

If the monetary authority is concerned about price level stability, the Taylor rule is modified as follows:

$$
1+r_{t}^{n}=R_{t}^{n}=\max \left\{1+0,\left[\left(\frac{P_{t} / \bar{P}_{t}}{\left(P_{t-1} / \bar{P}_{t-1}\right)^{\eta_{P}}}\right)^{\rho_{P}}\left(R^{n}\right)\right]^{1-\rho_{R N}}\left(R_{t-1}^{n}\right)^{\rho_{R N}}\right\}
$$

where $\bar{P}_{t}$ is the target or steady-state value for the price level at period $t$. Note that for $\eta_{P}=1$, the rule is the Taylor rule defined for inflation targeting, while $\eta_{P}=0$ signifies pure price-level targeting. For $0<\eta_{P}<1$ the rule is a hybrid one in which the central bank is concerned about reaching the inflation target rate but also about the evolution of prices on the way to the inflation target.

Figure 4 shows that the probability of hitting the ZLB is lower if the monetary authority decides to target the price level instead of the inflation rate. When agents are forward-looking and the monetary authority credibly commits to a PLT rule, such a rule yields a lower variability of inflation 
and of nominal interest rates. Agents expect that the monetary authority will correct the deviation from the target aiming at an above-average inflation rate. Private sector expectations of future inflation after a deflationary shock dampen the initial disinflation and - hence - stabilize interest rates. ${ }^{11}$ Therefore, a PLT rule will lower the probability to hit the ZLB for the nominal interest rate.

\section{The effectiveness of fiscal stimulus in times of crisis}

In this section, I explore whether fiscal policy is a good tool when the ZLB is hit. With the prospect of a severe global recession following the 2008-2009 crisis, many governments have put forward fiscal stimulus plans in order to underpin a recovery. As financial markets have played an important role in the 2007-2008 crisis, a strand of the literature has recently started investigating the role of fiscal policy in the presence of financial frictions (Röger and in’t Veld (2009), Erceg and Lindé (2009), Fernández-Villaverde (2010), Carillo and Poilly (2010)). In this section, I examine the effect of fiscal stimulus in an economy with frictions in financial markets and a binding constraint on nominal interest rates. Indeed, by the second half of 2008, many economies experienced a severe financial crisis and nominal interest rates in the U.S. and other major world economies reached historically low levels and in some cases have gone down close to zero. Following Corsetti, Kuester, Meier and Müller (2010), I do not distinguish between Ricardian and non-Ricardian

\footnotetext{
${ }^{11}$ Similar conclusions are reached by Giannoni (2010); Black, Macklem and Rose (1997); Vestin (2006).
} 
agents $^{12}$ and I assume an exogenous path for government expenditure. Fiscal stimulus is modelled as a $1 \%$ government spending shock that follows an $A R(1)$ process with a high degree of persistence $\left(\rho_{G}=0.9\right)$.

Figure 5 displays the response of total output and its components (namely, consumption and investment) to a risk premium shock in order to assess the effect of a fiscal stimulus. The series marked by spheres describes the reaction in a model affected only by the risk premium shock, while the series marked by triangles describes a model which allows also for the fiscal stimulus. Here, the fiscal stimulus is introduced as a temporary measure, implemented only at the first period. I distinguish two alternative specifications of the model: the baseline model with FA (Figure 5a) and the model with FA and the ZLB (Figure 5b). Figure 5 proves that if monetary policy is not constrained by the ZLB, the government spending shock leads to crowding-out of private investment and thus the expansionary effect of the fiscal stimulus is muted.

Table 2 (rows 2-5) displays the value of the government spending multiplier in the two alternative specifications of the model (with and without financial frictions) both in the case of a central bank who sets the interest rate according to the Taylor rule and in the case of a binding ZLB constraint. Again, the fiscal stimulus is implemented in the initial period. If the ZLB is

\footnotetext{
${ }^{12}$ I assume that all households are forward-looking and optimize their spending decisions. Recent literature has proposed to assume that many households are constrained to consume all their current income. The presence of constrained non-Ricardian households is in general conducive to raising the level of aggregate consumption in response to government spending shocks when compared with the specification without non-Ricardian households. However, some authors (e.g. Coenen and Straub (2005), Bilbiie, Meier and Müller (2008), Cogan, Cwick, Taylor and Wieland (2010)) have estimated that the share of non-Ricardian households is relatively low both in the U.S. and in the euro area. Therefore, there is only a fairly small chance that government spending shocks crowd-in aggregate consumption.
} 
not binding, the net impact on output is positive, but the value of the fiscal multiplier is below one. ${ }^{13}$ Moreover, the presence of financial frictions does not significantly affect the magnitude of the fiscal multiplier if the ZLB constraint is not binding. In contrast, when the ZLB is binding, the multipliers become larger in the model with the FA mechanism. Therefore, the combination of financial frictions and the ZLB increases the multiplier substantially: the government spending multiplier is slightly larger than one, as displayed in the fourth row of Table 2. The underlying intuition is that the FA mechanism is associated with large declines in output when the ZLB binds and hence is also associated with large values of the government-spending multiplier because the fiscal stimulus becomes more "powerful". In the model with financial frictions, the fiscal stimulus reduces the external finance risk premium and hence encourages investment. The crowding-out effect is negligible. There is therefore an additional gain which is lacking in the model without financial friction, where the fiscal stimulus has no impact on the net worth and on the external risk premium and public expenditures crowd-out private investments. This finding also confirms the results in Christiano, Eichenbaum and Rebelo (2011) that multipliers are larger in economies in which the output cost associated with the zero-bound problem is more severe, in this case in the economies with financial frictions.

These results prove that in a framework with financial frictions, the efficiency of government spending to stimulate output in more than a oneby-one basis depends not only on the presence of the ZLB, but also on the

\footnotetext{
${ }^{13}$ In this paper, I compute the cumulative fiscal multiplier, which is the short-term effect of fiscal stimulus is calculated over a one-year horizon. The multiplier is computed as $\sum_{t=1}^{4} \frac{\Delta Y_{t}}{\Delta G_{t}}$. For more detailed definition, see Iltzetzki, Mendoza and Végh (2010).
} 
presence of financial frictions. This finding is in line with those in FernándezVillaverde (2010) and Carillo and Poilly (2010), but it hinges on a different mechanism. In Fernández-Villaverde (2010) and Carillo and Poilly (2010), the mechanism works through the debt-deflation channel: by increasing inflation, government spending indirectly improves the balance sheet position of firms, which in turn reduces the external finance risk premium. On the contrary, this framework does not feature nominal liabilities and the reason for this result is that, with nominal interest rates held constant, the higher inflation generated by an expansionary fiscal policy will lead to a decrease in real interest rates and this channel support investment and amplifies the GDP impact of the fiscal stimulus. Therefore, results in favour of the fiscal stimulus in the proximity of the ZLB apply in a more general framework and do not necessary entail nominal liabilities.

Two practical objections to using fiscal policy, when the ZLB binds, have been raised. First, the duration of the fiscal stimulus turns out to be a crucial aspect to take into account in implementing fiscal policy, especially when the nominal interest rate is close to the ZLB. There exists a general agreement across models on the weak effects of a prolonged fiscal stimulus. Coenen et al. (2010) summarizes and compares the key results of a broad class of models. ${ }^{14}$ They find that, if fiscal expansion is not perceived to be temporary, it results in long-run crowding out of private spending. Second, there are long lags in implementing an increase in government spending. Christiano, Eichenbaum and Rebelo (2011) analyze the size of government spending multipliers in

\footnotetext{
${ }^{14}$ Specifically, the seven models considered are: the QUEST model (European Commission), the GIMF model (IMF), FRB-US and SIGMA (the Board of Governors of the Federal Reserve System, BoC-GEM (Bank of Canada), the NAWM model (European Central Bank), and the OECD Fiscal model.
} 
the presence of implementation lags. They find that the key determinant of the size of the multiplier is the state of the world in which new government spending comes on line. If it comes on line in future periods when the nominal interest rate is zero, there is a large effect on output. If it comes on line in future periods where the nominal interest rate is positive, the current effect of government spending is smaller. Indeed, "timing" seems to become a crucial aspect to take into account in implementing fiscal policy when the nominal interest rate is close to the ZLB. Corsetti, Meier and Müller (2009) and Corsetti, Kuester, Meier and Müller (2010) argue that the prospect of future spending cuts enhance the short-run stimulus effect, because it reduces inflation expectations and hence reduces the long-term interest rate. This argument holds also when the nominal short-term interest rate is bounded. Nevertheless, if monetary policy is constrained by the ZLB, the timing of the spending reversals is crucial. Reversing spending too early - while the ZLB is still binding and the economy is facing the risk of deflation - might further delay the exit from the ZLB. Postponing the reversal, instead, would reduce the stimulative short-term effects of fiscal policy.

Table 2 (row 6) displays the fiscal multiplier in case of a prolonged fiscal stimulus. In this case, the fiscal stimulus is still modelled as a $1 \%$ highly persistent shock to the government expenditure, but now it is implemented for 4 periods (namely, as long as the nominal interest rate is at the ZLB). In this case, the multiplier effect is still positive and higher than those arising in a situation in which the ZLB is not binding. Nevertheless, the prolonged fiscal stimulus is less effective than a temporary one.

Fiscal stimulus becomes even counter-productive, if it is expected to con- 
tinue beyond the point at which the ZLB ceases to bind. Table 2 (row 7) suggests that if the fiscal stimulus lasts 5 periods, it has contractionary effects on output, as shown by the negative value of the multiplier.

It has often been argued that one of the disadvantages of discretionary fiscal policy is that it is not timely, due to implementation lags. The last row of Table 2 shows the size of the government spending multiplier in the presence of implementation lags. If government spending still comes on line in future periods when the nominal interest rate is zero, but is delayed, the effects on output remain quite large, even though weaker than those generated by a "timely" fiscal intervention.

The size of fiscal multipliers depends sensitively on the model's parameter values and on the strength of the central bank's offsetting reaction. Some robustness checks prove that the relative magnitude of fiscal multipliers remains unaffected for alternative values of some key parameters. Therefore, the main conclusions remain unaltered. ${ }^{15}$

\section{Conclusions}

In this paper, I have analyzed the implications of the ZLB on nominal interest rates in a DSGE model with financial frictions. Three main findings are worth highlighting. First, in a framework with financial frictions, a binding

\footnotetext{
${ }^{15}$ Results are omitted for the sake of space. However, they are available upon request. In general, fiscal multipliers are larger if the central bank does not substantially change the policy rate, that is the central bank reacts weakly to inflation and output deviations. Multipliers are very robust to different specifications of the Taylor rule in the model without financial frictions. See Williams (2009) for further discussion on the implications of setting a Taylor rule that reacts aggressively to movements in the output gap, when the interest rate is in the vicinity of the ZLB.
} 
constraint on nominal interest rates amplifies the recession. Second, following a deflationary shock, a PLT rule makes the ZLB less likely to be hit, because the private sector's expectations of future inflation after a deflationary shock dampen the initial disinflation and hence stabilize interest rates. Third, an increase in government spending cushions the output fall but leads to crowding-out of private consumption. Therefore, the net impact of a fiscal stimulus on output is still positive, but the value of the fiscal multiplier is below one. However, the combination of a binding ZLB constraint and financial frictions amplifies the expansionary effects of the government spending shock and generates fiscal multipliers larger than one. The underlying reason is that in the model with financial frictions, the fiscal stimulus reduces the external finance risk premium and hence encourages investment. There is therefore an additional gain which is lacking in the model without financial friction, where the fiscal stimulus has no impact on the net worth and on the external risk premium and where public expenditures crowd-out private investments.

Concerning the effectiveness of the fiscal stimulus when the nominal interest rate is close to the ZLB, two further results are worth highlighting. First, the duration of fiscal stimulus turns out to be a crucial aspect to take into account in implementing fiscal policy. If the fiscal stimulus continues beyond the period at which the ZLB ceases to bind, then it has contractionary effects on output. Second, the presence of lags in implementing discretionary fiscal policy might weaken the expansionary effects on output. Nevertheless, if government spending is delayed but still comes on line in future periods when the nominal interest rate is zero, the stimulative effect on output remains 
quite large.

One should aware that fiscal multipliers are very sensitive to how the original stimulus is financed. Therefore, a further step might be to distinguish effects of different types of fiscal instruments. 


\section{References}

[1] Adam, K. and R. Billi (2006), "Optimal monetary policy under commitment with a zero bound on nominal interest rates", Journal of Money, Banking and Credit, Vol.38, No. 7, pp. 1877-1905.

[2] Amano, R. and Ambler, S. (2008), "Inflation targeting, price-level targeting and the zero lower bound", paper presented at the New Perspectives on Monetary Policy Design conference, jointly organized by CREI and the Bank of Canada, October 10-11, 2008.

[3] Amano, R. and M. Shukayev (2009), "Risk premium shocks and the zero lower bound on nominal interest rates", Bank of Canada Working Papers No. 27/2009.

[4] Bernanke, B., and M. Gertler (1989), "Agency costs, net worth and business fluctuations", American Economic Review 79, pp.14-31.

[5] Bernanke, B., and M. Gertler (1995), "Inside the black box: the credit channel of monetary policy transmission", Journal of Economic Perspectives 9 , pp. 27-48.

[6] Bernanke, B., M. Gertler, and S. Gilchrist (1998), "The financial accelerator in a quantitative business cycle framework", NBER Working Papers No. 6455, March.

[7] Bernanke, B., Reinhart, V. and B. Sack (2004), "Monetary policy alternatives at the zero bound: an empirical assessment", Federal Reserve Board Finance and Economics Discussion Series, Working Papers No. 48, Washington DC.

[8] Bilbiie, F.O., Meier, A. and G. Müller (2008), "What accounts for the changes in U.S. fiscal policy transmission?" Journal of Money, Credit and Banking, Vol. 40, No. 7, pp. 1439-1470.

[9] Bodenstein, M., Erceg, C. J. and L. Guerrieri (2009), "The effects of foreign shocks when U.S. interest rates are at zero", International Finance Discussion Papers No. 983, Board of Governors of the Federal Reserve System. 
[10] Buiter, W.H. and N. Panigirtzoglou (2000), "Liquidity traps: how to avoid them and how to escape them", Bank of England Working Papers Series, No. 11.

[11] Carillo, J.A. and C. Poilly (2010), "Investigating the ZLB on the nominal interest rate under financial instability", Research Memoranda 019 Maastricht: METEOR.

[12] Cateau, G. and Dorich, J. (2011), "Price-level targeting, the zero bound on the nominal interest rate and imperfect credibility", Bank of Canada preliminary manuscript.

[13] Christensen I. and A. Dib (2006), "Monetary policy in an estimated DSGE model with a financial accelerator", Bank of Canada Working Papers No. 06-09.

[14] Christiano, L. J. (2004), "The zero-bound, zero-inflation targeting, and output collapse", manuscript, Northwestern University.

[15] Christiano, L. J., Eichenbaum, M. and S. Rebelo (2011), "When is the government spending multiplier large?", Journal of Political Economy, Vol. 119, No 1, pp. 78-121.

[16] Coenen, G., Orphanides, A. and V. Wieland (2003), "Price stability and monetary policy effectiveness when nominal interest rates are bounded at zero", ECB Working Papers No. 231, May.

[17] Coenen, G. and R. Straub (2005), "Does government spending crowd in private consumption? Theory and empirical evidence for the Euro Area," International Finance, Vol. 8, No. 3, pp. 435-470.

[18] Coenen, G., Erceg, C., Freedman, C., Furceri, D., Kumhof, M., Ladonde, R., Laxton, D., Lindé, J., Mourougane, A., Muir, D., Mursula, S., de Resende, C., Roberts, J., Roeger, W., Snudden, S., Trabandt, M. and J. in 't Veld (2010), "Effects of fiscal stimulus in structural models", IMF Working Papers No. 10/73, March.

[19] Cogan, J. F., Cwik, T., Taylor, J. B. and V. Wieland (2010), "New Keynesian versus old Keynesian government spending multipliers", Journal of Economic Dynamics and Control, Vol. 34, No. 3, pp. 281-295. 
[20] Coibon, O., Gorodnichenko, Y. and Wieland, J. (2010), "The optimal inflation rate in New Keynesian models", NBER Working Papers No. 16093.

[21] Corsetti, G., Meier, A. and G. Müller (2009), "Fiscal stimulus with spending reversals", IMF Working Papers No. 106, May.

[22] Corsetti, G., Kuester, K., Meier A., and G. Müller (2010), "Debt consolidation and fiscal stabilization of deep recessions", American Economic Review, Vol. 100, No.2, pp. 41-45, May.

[23] Covas, F. and Y. Zhang (2010), "Price-level versus inflation targeting with financial market imperfections", Canadian Journal of Economics, Vol. 43, No. 4, pp. 1302-1332, November.

[24] De Graeve, F. (2008), "The external finance premium and the macroeconomy: U.S. post-WWII evidence", Journal of Economic Dynamic and Control, Vol. 32, No. 11, pp. 3415-3440, November.

[25] Eggertsson, G. and M. Woodford (2003), "Optimal monetary policy in a liquidity trap", NBER Working Papers No. 9968.

[26] Eggertsson, G. and M. Woodford (2004), "Optimal monetary and fiscal policy in a liquidity trap", NBER Working Papers No. 10840.

[27] Erceg, J.C. and J. Lindé (2010), "Is there a fiscal free lunch in a liquidity trap?", CEPR Discussion Papers No. 7624.

[28] Fernández-Villaverde, J.F. (2010), "Fiscal Policy in a model with financial frictions", American Economic Review, Vol. 100, No.2, pp. 35-40, May.

[29] Gaspar, V. and Smets, F. (2000), "Price level stability: some issues", National Institute Economic Review No. 174, pp. 68-79.

[30] Gertler, M., Gilchrist, S. and F. Natalucci (2007), " External constraints on monetary policy and the financial accelerator", Journal of Money, Credit and Banking, Vol. 39, pp. 295-330.

[31] Gilchrist, S. , Sim, J. and E. Zakrajšek (2010), "Uncertainty, Financial Frictions, and Investment Dynamics", mimeo. 
[32] Goodfriend, M. (2000), "Overcoming the zero bound on interest rate policy", Journal of Money, Credit and Banking, Vol. 32, No. 4, part 2, pp 1007-1035.

[33] Ilzetzki, E., Mendoza, E.G. and C. A. Végh (2011), "How big (small?) are fiscal multipliers?" IMF Working Papers No. 11/52.

[34] Krugman, P.R. (1998), "It's back: Japan's slump and the return of the liquidity trap", Brookings Papers on Economic Activity, No. 2, pp. 137-205.

[35] Lewis, K.A. and L.S. Seidman (2008), "Overcoming the zero interest rate bound: a quantitative prescription", Journal of Policy Modelling, Vol. 30, No. 5, pp. 751-760.

[36] Lipsky, J. (2011), "U.S. fiscal policy and the global outlook", Journal of Policy Modelling, Vol. 33, pp. 717-722.

[37] Queijo, V. (2009), "How important are financial frictions in the U.S. and the Euro Area?", Scandinavian Journal of Economics, Vol. 111, No. 3, pp. 567-596.

[38] Reifschneider, D. and J. C. Williams (2000), "Three lessons for monetary policy in a low-inflation era", Journal of Money Credit and Banking, Vol. 32, pp. 936-966.

[39] Schmitt-Grohe, S. and M. Uribe (2007), "Optimal inflation stabilization in a medium-scale macroeconomic model", in Monetary Policy Under Inflation Targeting, edited by Klaus Schmidt-Hebbel and Frederic Mishkin, Central Bank of Chile, Santiago, Chile.

[40] Romer, C. and J. Bernstein (2009), " The job impact of the American Recovery and Reinvestment Plan", Council of Economic Adviser.

[41] Smets, F. (2000), "What horizon for price stability?", ECB Working Papers Series, No. 24.

[42] Smets, F. and R. Wouters (2007), "Shocks and frictions in U.S. business cycles: a Bayesian DSGE approach," American Economic Review, American Economic Association, Vol. 97, No. 3, pp. 586-606, June. 
[43] Svensson, L.E.O. (2000), "How should monetary policy be conducted in an era of price stability?", NBER Working Papers Series, No. 7516.

[44] Svensson, L.E.O. (2001), "The zero bound in an open economy, a fool proof way of escaping from a liquidity trap", Bank of Japan Monetary and Economic Studies, Vol. 19, No. S-1, pp. 277-312.

[45] Viñals, J. (2001), "Monetary policy in a low inflation environment", Banco de España Working Papers, No. 0107.

[46] Williams, J.C. (2009), "Heeding Daedalus comment and discussion optimal inflation and the zero lower bound", Brookings Papers on Economic Activity, 2, pp. 1-37.

[47] Woodford, M. (2011), "Simple analytics of the government expenditure multiplier", American Economic Journal: Macroeconomics, Vol. 3, No 1, pp.1-35.

[48] Yates, T. (2002), "Monetary policy and the zero bound to interest rates: a review", European Central Bank Working Papers No. 190, October. 

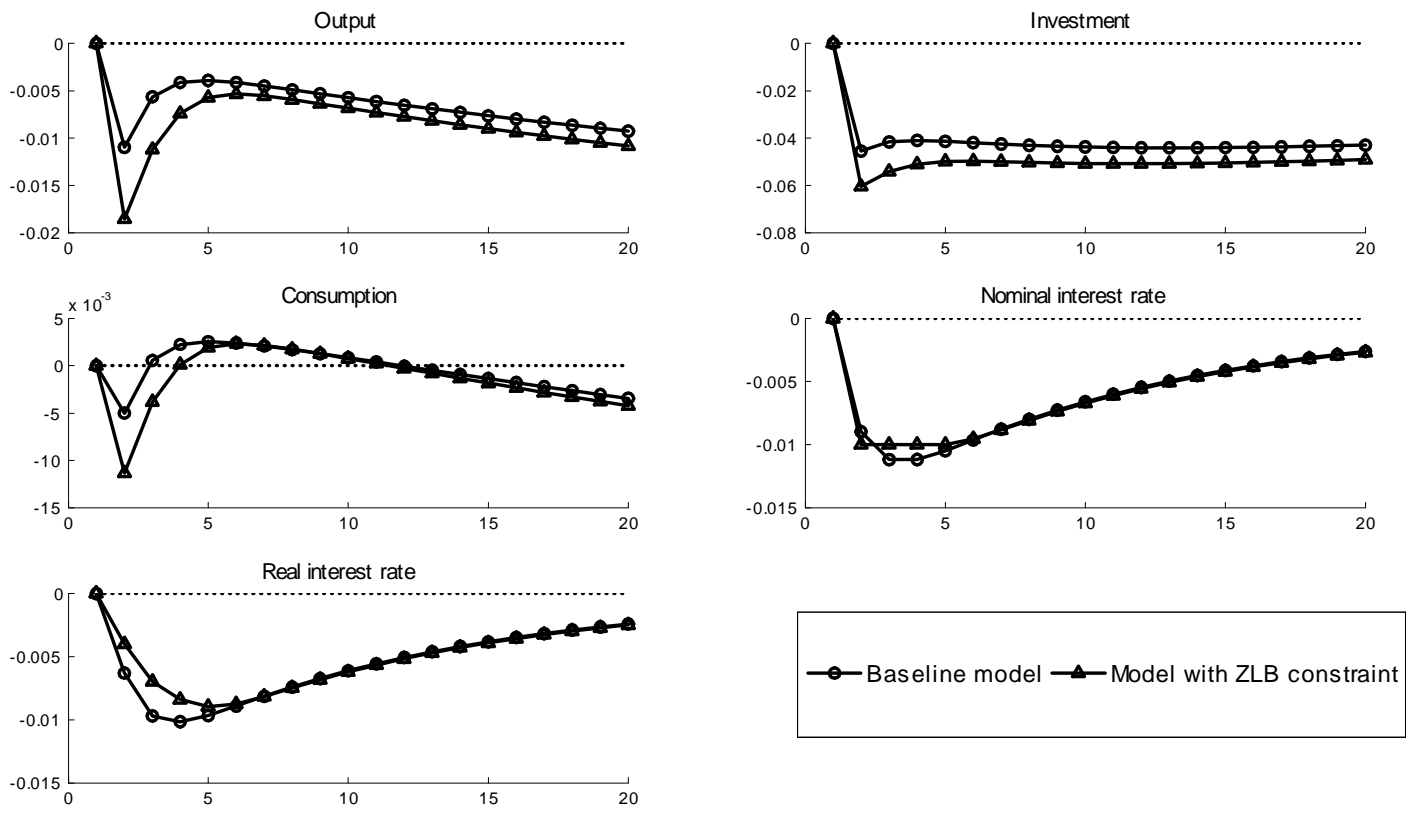

Figure 1: Risk premium shock 

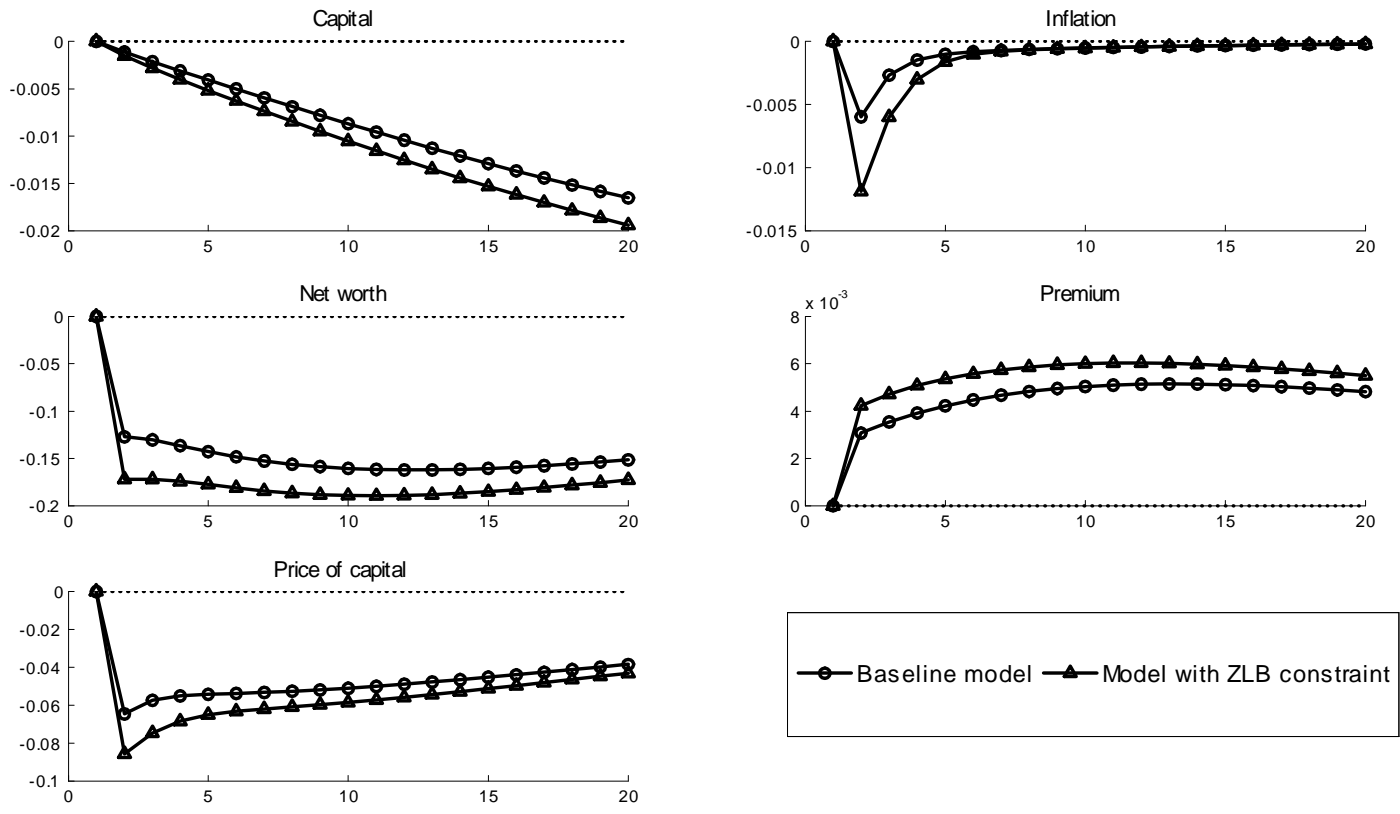

Figure 1 bis: Risk premium shock 

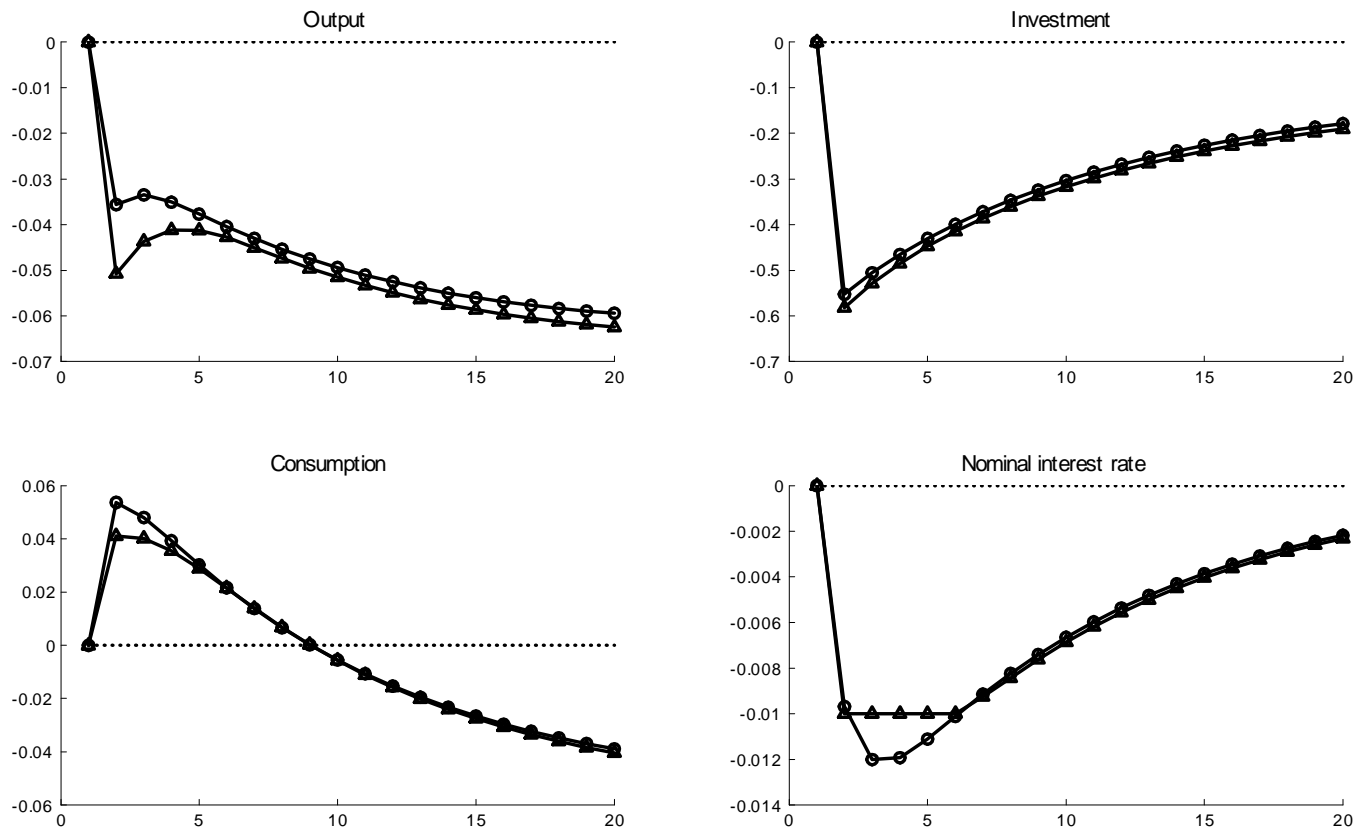

Figure 2: Financial shock 

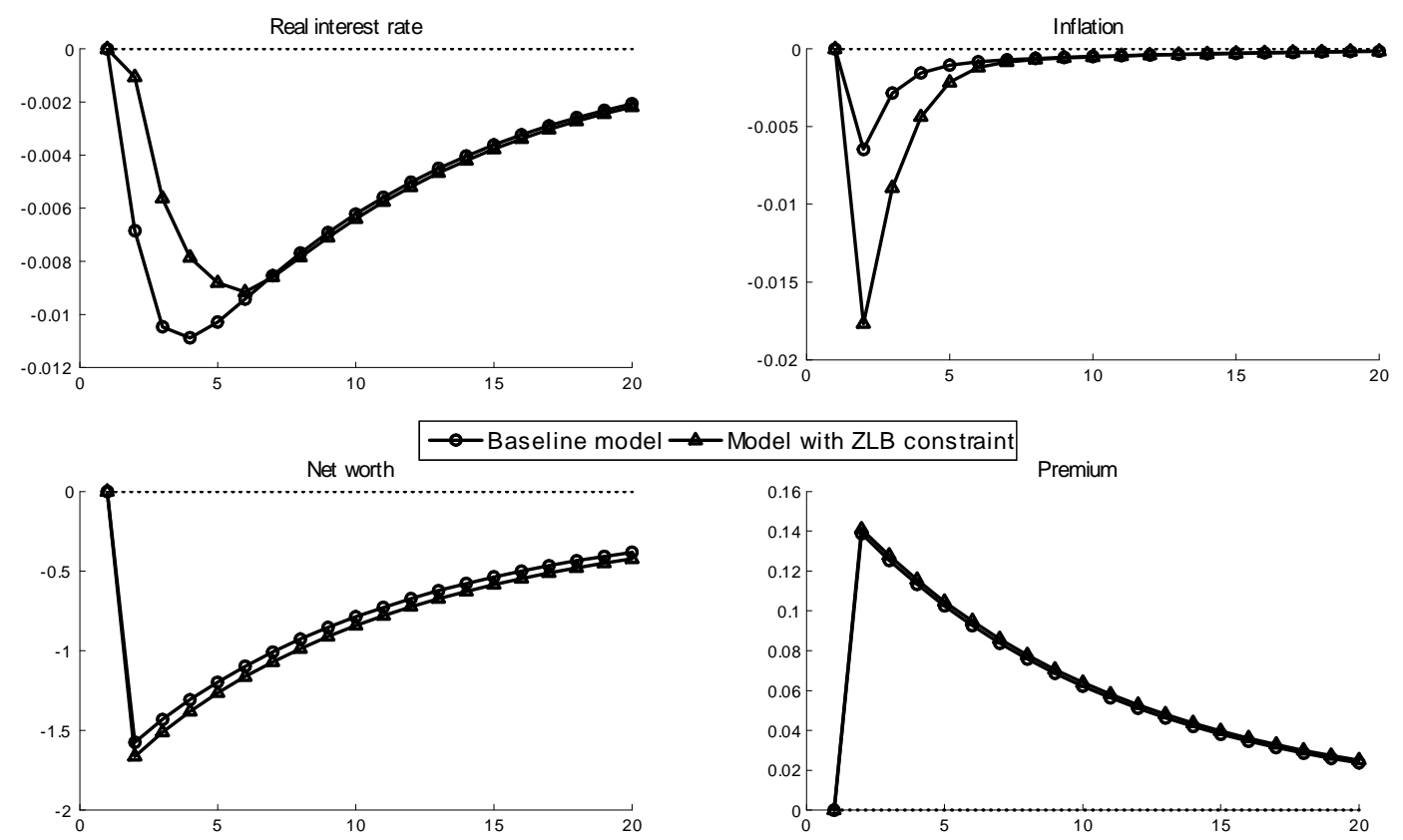

Figure 2 bis: Financial shock 

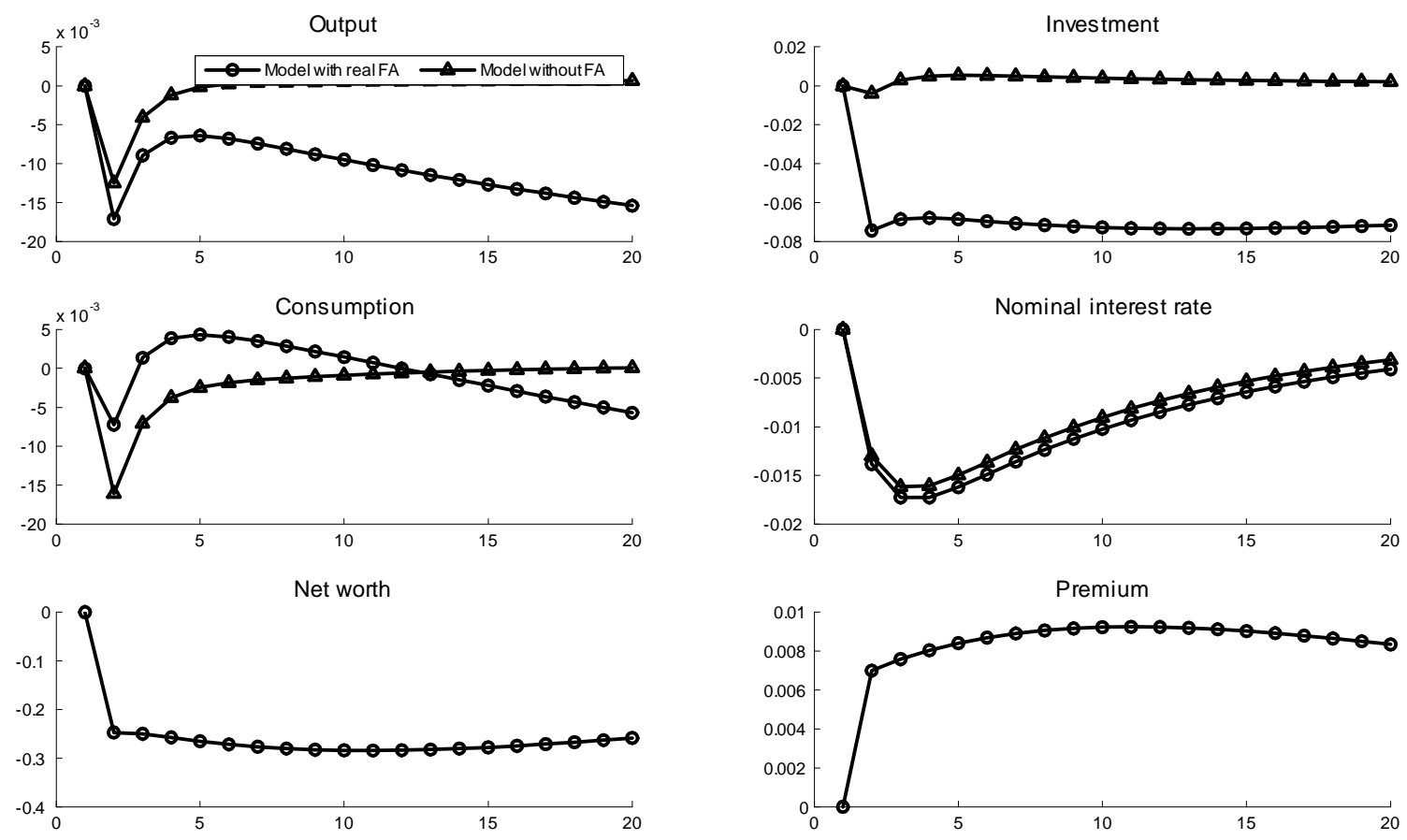

Figure 3: Risk premium shock (model with and without FA mechanism)

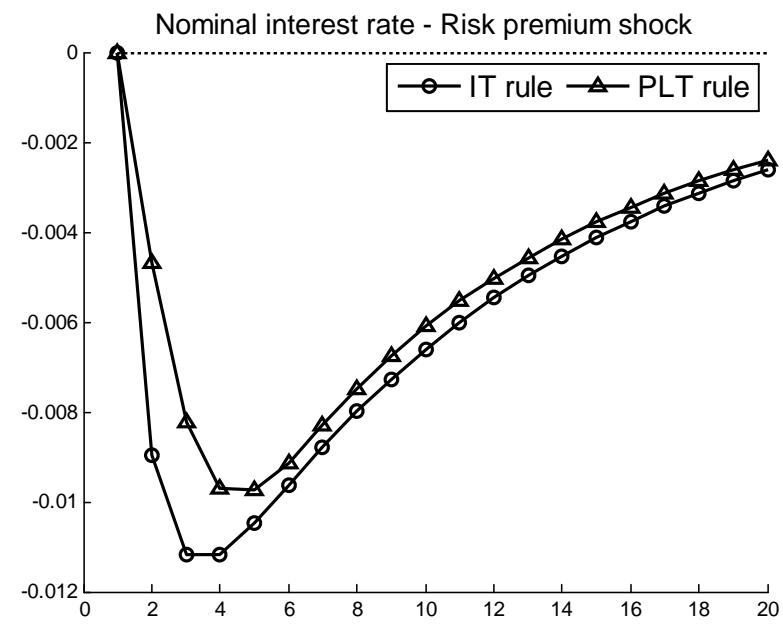

Figure 4a: Risk premium shock 


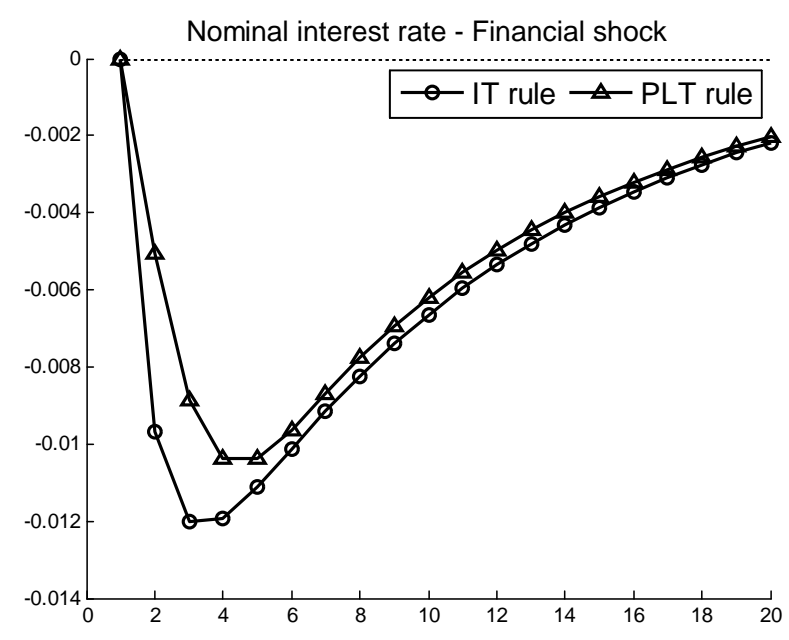

Figure 4b: Financial shock
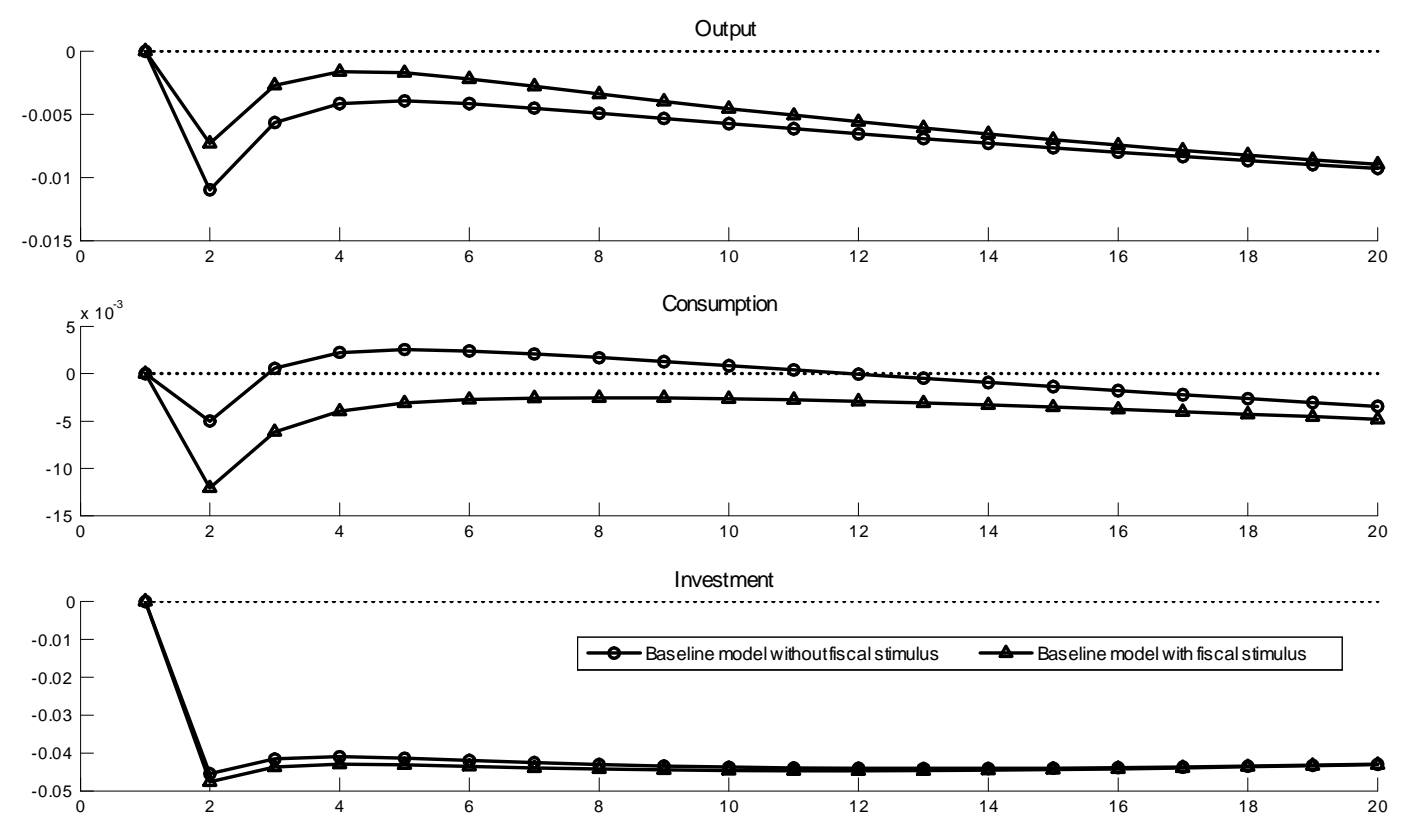

Figure 5a: Fiscal stimulus and risk premium shock in the baseline model with FA 

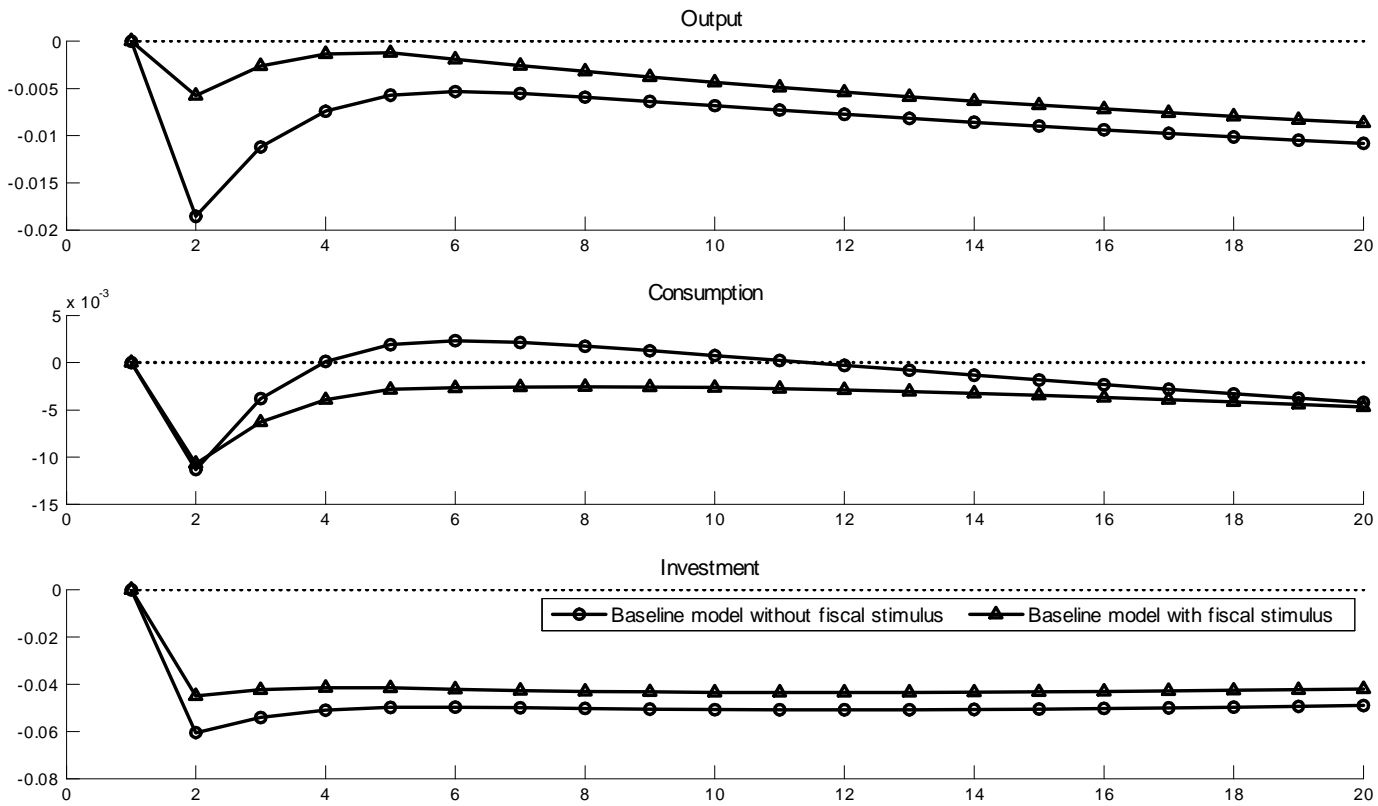

Figure 5b: Fiscal stimulus and risk premium shock in the model with FA and the ZLB 


\begin{tabular}{|c|c|c|c|}
\hline \multicolumn{2}{|c|}{ Parameter } & \multirow{2}{*}{$\begin{array}{l}\text { Value } \\
0.025\end{array}$} & References \\
\hline$\delta$ & Capital depreciation rate & & \\
\hline$\beta$ & Discount factor & 0.99 & \\
\hline$\sigma$ & Relative risk aversion & 1.2 & \\
\hline$\alpha$ & Share of capital in the final good production & 0.35 & BGG (1998) \\
\hline$\psi$ & Elasticity of labour supply & 1 & CMR (2010) \\
\hline$\frac{\vartheta}{\vartheta-1}-1$ & Price mark-up & 0.2 & CD (2006); GGN (2007) \\
\hline$\varphi$ & Calvo price adjustment & 0.75 & BGG (1998);CMR (2010) \\
\hline$\gamma_{\pi}$ & Responce to inflation in the Taylor rule & 1.5 & \\
\hline$\gamma_{R N}$ & Interest rate smoothing & 0.8 & \\
\hline$\chi$ & Investment adjustment costs & 1.42 & see GSZ (2010) \\
\hline & Steady-state of the leverage ratio & 2 & BGG (1998); CMR (2010) \\
\hline & Share of surviving entrepreneurs & 0.9728 & BGG (1998); CMR (2010) \\
\hline$F-R$ & Steady-state of external risk premium & 350 b.p. & GGN (2007) \\
\hline \multicolumn{4}{|c|}{$\begin{array}{l}\text { BGG = Bernanke, Gertler annd Gilchrist } \text { CMR=Christiano, Motto and Rostagno; } \\
\text { GSZ=Gilchrist, Sim and Zakrajšek; } \\
\text { GGN=Gertler, Gilchrist and Natalucci } \mathrm{CD}=\text { Christensen adn Dib }\end{array}$} \\
\hline
\end{tabular}

Table 1: Calibrated parameters

\begin{tabular}{||l|l|l||}
\hline \hline Model specification & Fiscal stimulus & $\sum_{t=1}^{4} \frac{\Delta Y_{t}}{\Delta G_{t}}$ \\
\hline Model with FA & temporary & 0.335 \\
Model without FA & temporary & 0.336 \\
Model with FA+ZLB & temporary & 1.015 \\
Model without FA+ZLB & temporary & 0.959 \\
Model with FA+ZLB & prolonged as long as the ZLB binds & 0.450 \\
Model with FA+ZLB & prolonged beyond the ZLB binds & -0.474 \\
Model with FA+ZLB & delayed & 0.922 \\
\hline \hline
\end{tabular}

Table 2: Government spending multipliers 
Institut de Recherches Économiques et Sociales

Université catholique de Louvain

Place Montesquieu, 3

1348 Louvain-la-Neuve, Belgique 